\title{
Effectiveness of intramuscular neostigmine to accelerate bladder emptying after spinal anesthesia
}

This article was published in the following Dove Press journal:

Therapeutics and Clinical Risk Management

\section{Tjokorda Gde Agung \\ Senapathi \\ Made Wiryana \\ I Made Subagiartha \\ I Putu Pramana Suarjaya \\ I Made Gede Widnyana \\ Ida Bagus Krisna Jaya \\ Sutawan \\ A A Gde Putra Semara Jaya \\ Andri Thewidya}

Department of Anesthesiology and Intensive Care, Sanglah Hospital, Faculty of Medicine, Udayana University, Denpasar, Bali, Indonesia

Correspondence: A A Gde Putra

Semara Jaya

Department of Anesthesiology and

Intensive Care, Sanglah Hospital, Faculty

of Medicine, Udayana University,

Diponegoro Street, Denpasar 80II4,

Bali, Indonesia

Tel +62 36 I25 736 |

Fax +62 $36 \quad I 235980$

Email gungthey84@yahoo.com
Purpose: Postoperative urinary retention (POUR) is one of the most common complications following spinal anesthesia. Spinal anesthesia may influence urinary bladder function due to interruption of the micturition reflex. Urinary catheterization is the standard treatment of POUR. Urinary catheter insertion is an invasive procedure, which is associated with catheterrelated infections, urethral trauma, and patient discomfort. The purpose of this study was to determine the effectiveness of intramuscular (IM) neostigmine to accelerate bladder emptying after spinal anesthesia.

Patients and methods: A total of 36 patients undergoing lower abdominal (except for pelvic, urologic, anorectal, and hernia surgery) and lower extremity surgery under spinal anesthesia were divided into two groups randomly $(n=18)$, to either neostigmine $(\mathrm{N})$ group or control (C) group. Neostigmine $0.5 \mathrm{mg}$ ( $\mathrm{N}$ group) or $\mathrm{NaCl} 0.9 \%$ (C group) was administered intramuscularly when Bromage score 0 and sensory level sacral two have been achieved. The time to first voiding after IM injection and the time to first voiding after spinal anesthesia were measured.

Results: The time to first voiding after IM injection was significantly faster $(P \leq 0.05)$ in the $\mathrm{N}$ group than that in the $\mathrm{C}$ group, with median time as 40 minutes (20-70 minutes) and 75 minutes (55-135 minutes), respectively. Time to first voiding after spinal anesthesia was also significantly faster $(P \leq 0.05)$ in the $\mathrm{N}$ group than that in the $\mathrm{C}$ group (mean of $280.8 \pm 66.6$ minutes and 364.2 \pm 77.3 minutes, respectively).

Conclusion: IM neostigmine effectively accelerates bladder emptying after spinal anesthesia. Keywords: neostigmine, postoperative urinary retention, bladder emptying, spinal anesthesia, anticholinesterase, neuraxial anesthesia

\section{Introduction}

Postoperative urinary retention (POUR) is a common complication after anesthesia and surgery; the incidence rate varies from 5\% to 70\%. Type of surgery, type of anesthesia, analgesics, anticholinergics, and comorbidities may predispose patients to development of POUR. ${ }^{1-4}$ POUR is one of the most common complications following spinal anesthesia. Spinal anesthesia may influence urinary bladder function due to interruption of the micturition reflex. The duration of these disturbances depends on both the potency and administered dose of local anesthetics. ${ }^{1,5,6}$

Kamphuis et $\mathrm{al}^{5}$ in their study concluded that spinal anesthesia with lidocaine and bupivacaine causes a clinically significant disturbance in bladder function. The urge to void disappears quickly after spinal injection of the local anesthetics. Similarly, a systematic review by Choi et $\mathrm{al}^{6}$ also concluded that neuraxial anesthesia/analgesia results 
in transient detrusor dysfunction. The duration of dysfunction depends on the potency and dose of medication used.

Postoperative urine retention has been defined as the inability to void in the presence of a full bladder. Clinical examination and ultrasonographic assessment can be used to diagnose POUR. At least there were five different calculation methods to measure urinary bladder volume in real time. Catheterization is recommended if the patient is unable to void with at a bladder volume $>600 \mathrm{~mL}$ detected by ultrasound. Urinary catheter insertion is an invasive procedure, which is associated with catheter-related infections, urethral trauma, and patient discomfort. ${ }^{1,7-9}$

There are various medications for treatment of POUR, including cholinergic agents, anticholinesterase agents, alpha-blockers, sedatives and prostaglandin. ${ }^{10,11}$ Neostigmine is an acetylcholinesterase inhibitor or anticholinesterase agent. It causes accumulation of acetylcholine around the cholinergic nerve terminals. Urinary bladder contraction is critically dependent on acetylcholine-induced stimulation of contractile muscarinic receptors on the smooth muscle (detrusor) of the urinary bladder. ${ }^{11-13}$

Bałkota et $\mathrm{al}^{14}$ analyzed the efficacy of the intramuscularly administered neostigmine in the prevention of POUR in the patients who underwent orthopedic procedures under spinal anesthesia. However, the results were not statistically significant.

Through this research, we tried to determine the effectiveness of intramuscular (IM) $0.5 \mathrm{mg}$ neostigmine to accelerate bladder emptying after spinal anesthesia.

\section{Patients and methods}

\section{Patients}

This is an experimental study with a double-blind, randomized, controlled trial design. A total of 36 patients aged 18-50 years with American Society of Anesthesiologists (ASA) physical status I-II undergoing lower abdominal (except for pelvic, urologic, anorectal, and hernia surgery) and lower extremity surgery under spinal anesthesia in the central operating theater at Sanglah Hospital (Joint Commission International - Accredited) from October through December 2017 were admitted to the study. Patients were not admitted to the study if any the following criteria were present: patient refusal, contraindications using local anesthetics, contraindications to neostigmine, local infection at the site of injection, urinary tract symptoms (frequency, incontinence, enuresis, nocturia, hesitancy, urgency, weak stream, dysuria, and inability to empty the bladder fully), surgical duration $>2$ hours, and intraoperative blood loss $>200 \mathrm{~mL}$. After the subjects were assessed for eligibility, random assignment was done using the block randomization method.

\section{Procedures}

Patients were allowed to drink clear fluid up to $200 \mathrm{~mL}$ until 2 hours before induction of anesthesia. All patients were asked to urinate before transfer to the central operating theater. Intravenous access was obtained, and ringer lactate infusion was started in the preparation room of central operating theater. In the operating room, standard monitoring (electrocardiography, noninvasive blood pressure, and pulse oximetry) was installed and the subjects received oxygen supplementation $2 \mathrm{~L} / \mathrm{min}$ through a nasal cannula. Spinal anesthesia was done using Quincke-type needle G27 using $0.5 \%$ hyperbaric bupivacaine. The height of the block based on skin dermatome was performed by the pinprick test.

After the surgery was finished, in the postoperative care unit, the subjects either received $0.5 \mathrm{mg}$ IM neostigmine ( $\mathrm{N}$ group) or IM NaCl 0.9\% (C group). IM injection was performed when Bromage score (motor block assessment) 0 was achieved and height of the sensory block reached a level of S2 dermatome. Urinary bladder ultrasound was performed hourly until spontaneous micturition occurred. If POUR occurred (inability to void with at a bladder volume $>600 \mathrm{~mL}$ detected by ultrasound), then they will be catheterized. The prolate ellipsoid method was used to measure urinary bladder volume based on the formula volume $=$ length $\times$ width $\times$ height $\times 0.52$ on a two-dimensional image.

Local anesthetic dose for spinal anesthesia, level of sensory block, surgical duration, the amount of intraoperative fluid, urinary bladder volume before IM injection, time to first voiding after IM injection, time to first voiding after spinal anesthesia, volume of urine excreted, postvoid residual volume, and patients who needed urinary catheterization were measured.

\section{Statistical analyses}

All statistical analyses were conducted using SPSS for Windows (IBM Corporation, Armonk, NY, USA) software version 20. Data were assessed for their conformance to the normal distribution using the Shapiro-Wilk test. Numerical variables were expressed as mean \pm SD or median (minimummaximum), and categorical variables were expressed as frequency (\%). Independent $t$-test was used to compare mean values if data distribution was normal, or nonparametric Mann-Whitney $U$ test was used if data were not distributed normally. Categorical variables were assessed using $\chi^{2}$ or 
Fischer's exact test. Results were considered as significant at $P<0.05$.

\section{Ethics statements}

This research was approved by research ethics committee of Faculty of Medicine Udayana University and Sanglah Hospital. All subjects gave written informed consent and were fully informed of the procedures prior to participation in the studies.

\section{Results}

There were no significant differences $(P>0.05)$ in both groups in terms of sex, age, body mass index, and ASA physical status (Table 1). As given in Table 2, local anesthetic dose for spinal anesthesia, level of sensory block, surgical duration, and the amount of intraoperative fluid were not significantly different between two groups $(P>0.05)$.

Postoperatively (Table 3 ), urinary bladder volume before IM injection was not significantly different between two groups $(P>0.05)$. Time to first voiding after IM injection was significantly faster $(P \leq 0.05)$ in the $\mathrm{N}$ group than that in the $\mathrm{C}$ group, with median time as 40 minutes (20-70 minutes) and 75 minutes (55-135 minutes), respectively. Time to first voiding after spinal anesthesia was also significantly faster $(P \leq 0.05)$ in the $\mathrm{N}$ group than that in the $\mathrm{C}$ group (mean of $280.8 \pm 66.6$ minutes and $364.2 \pm 77.3$ minutes, respectively).

Volume of urine excreted was higher in the $\mathrm{C}$ group than that in the $\mathrm{N}$ group with median volume as $322 \mathrm{~mL}(150-400 \mathrm{~mL})$ and $230 \mathrm{~mL}(150-400 \mathrm{~mL})$, respectively, but was not significantly different $(P>0.05)$. Postvoid residual volume was significantly lower $(P \leq 0.05)$ in the $\mathrm{N}$ group than that in the $\mathrm{C}$ group (mean of $112.5 \pm 17.8$ minutes and $190 \pm 23.3$ minutes, respectively). One (5.6\%) subject in the $\mathrm{N}$ group and three (16.7\%) subjects in the $\mathrm{C}$ group were catheterized due to urinary retention but did not differ significantly $(P>0.05)$.

Table I Subject characteristics

\begin{tabular}{llll}
\hline Characteristics & \multicolumn{2}{l}{ Groups } & P-value \\
\cline { 2 - 3 } & $\mathbf{N}(\mathbf{n}=\mathbf{I} \mathbf{8})$ & $\mathbf{C}(\mathbf{n}=\mathbf{I} \mathbf{8})$ & \\
\hline Sex & & & \\
$\quad$ Male & $(44.4 \%)$ & $8(44.4 \%)$ & $1.000^{\mathrm{a}}$ \\
$\quad$ Female & $10(55.6 \%)$ & $10(55.6 \%)$ & \\
Age (years) & $34.1 \pm 12.9$ & $37.5 \pm 13.7$ & $0.443^{\mathrm{b}}$ \\
BMI (kg/m $\left.{ }^{2}\right)$ & $22.3 \pm \mathrm{I} .5$ & $22.5 \pm 2.5$ & $0.763^{\mathrm{b}}$ \\
ASA physical status & & & \\
ASA I & $9(50 \%)$ & $9(50 \%)$ & $1.000^{\mathrm{a}}$ \\
ASA II & $9(50 \%)$ & $9(50 \%)$ & \\
\hline
\end{tabular}

Notes: Values are expressed as mean \pm SD for numerical data and frequency (\%) for categorical data. ${ }^{a} \chi^{2}$ test. ${ }^{b}$ Independent $t$-test.

Abbreviations: ASA, American Society of Anesthesiologist; BMI, body mass index $\mathrm{C}$, control group; $\mathrm{N}$, neostigmine group; $\mathrm{n}$, number of subjects.
Table 2 Intraoperative

\begin{tabular}{llll}
\hline Intraoperative & Groups & P-value \\
\cline { 2 - 3 } & $\mathbf{N}(\mathbf{n}=1 \mathbf{8})$ & $\mathbf{C ~ ( n = 1 8 )}$ & \\
\hline $\begin{array}{l}\text { Local anesthetic } \\
\text { dose (mg) }\end{array}$ & $12.5(10-15)$ & $15(7.5-15)$ & $0.237^{\mathrm{a}}$ \\
$\begin{array}{l}\text { Sensory block } \\
\text { level }(\mathrm{T})\end{array}$ & $8(6-9)$ & $7(6-10)$ & $0.399^{\mathrm{a}}$ \\
$\begin{array}{l}\text { Surgical duration } \\
\text { (minutes) }\end{array}$ & $81.5 \pm 26.6$ & $77.8 \pm 34.1$ & $0.717^{\mathrm{b}}$ \\
$\begin{array}{l}\text { Volume of IV } \\
\text { fluid }(\mathrm{mL})\end{array}$ & $\mathrm{I}, 000(500-1,000)$ & $\mathrm{I}, 000(500-1,500)$ & $0.063^{\mathrm{a}}$ \\
\hline
\end{tabular}

Notes: Values are expressed as mean \pm SD or median (minimum-maximum) for numerical data and frequency (\%) for categorical data. ${ }^{a}$ Independent $t$-test. ${ }^{b} M a n n-$ Whitney $U$ test.

Abbreviations: C, control group; IV, intravenous; N, neostigmine group; n, number of subjects; $\mathrm{T}$, thoracic dermatome.

\section{Discussion}

Spinal anesthesia is a common anesthesia technique used in patients undergoing abdominal and lower extremity surgery. POUR is one of the most common complications following spinal anesthesia. Intrathecal local anesthetics inhibit the transmission of the afferent and efferent action potentials on the nervous fibers of the sacral spinal cord segments (S2-S4) from and to the bladder. The feeling of urgency to void disappears 30-60 seconds after spinal anesthesia, but a dull sensation of tension on maximal filling of the bladder persists. Inhibition of the afferent nerve fibers' transmission from the bladder to the micturition center in the brain leads to bladder analgesia. The detrusor contraction is completely abolished 2-5 minutes after the intrathecal local anesthetics injection. The recovery of detrusor muscle activity depends on the duration of sensory block above the S2 and S3 sacral segments. ${ }^{1,5,6}$

Neostigmine is an acetylcholinesterase inhibitor that causes accumulation of acetylcholine around the cholinergic nerve terminals. It causes concentration-dependent contractions in rat urinary bladder. Acetylcholine will stimulate contractile muscarinic receptors on the smooth muscle (detrusor) of the urinary bladder and lead to urinary bladder contraction. Prolonged duration of acetylcholine in the receptor gives rise to stronger smooth muscle contraction. ${ }^{11-13}$

The function of the bladder is regulated by an interaction between the somatic, parasympathetic and sympathetic nervous systems. Parasympathetic nervous system provides the major excitatory innervation of the detrusor muscle. Stimulation of postsynaptic muscarinic receptors M2 and M3 is considered as the most important, although many receptor systems and mediators are responsible for detrusor contraction. In terms of quantity, the M2 subtype dominates over the 
Table 3 Postoperative

\begin{tabular}{|c|c|c|c|}
\hline \multirow[t]{2}{*}{ Postoperative } & \multicolumn{2}{|l|}{ Groups } & \multirow[t]{2}{*}{$P$-value } \\
\hline & $\mathbf{N}(n=18)$ & $C(n=18)$ & \\
\hline Urinary bladder volume before treatment $(\mathrm{mL})$ & $445.6 \pm 75.9$ & 486. $1 \pm 72.4$ & $0.110^{\mathrm{a}}$ \\
\hline \multirow[t]{2}{*}{ Time to first voiding after treatment (minutes) } & $41.9 \pm 12.3$ & $89.4 \pm 26.1$ & $<0.00 \mathrm{I}^{\mathrm{b}}$ \\
\hline & $40(20-70)$ & $75(55-135)$ & \\
\hline Time to first voiding after spinal anesthesia (minutes) & $280.8 \pm 66.6$ & $364.2 \pm 77.3$ & $0.001^{\mathrm{a}}$ \\
\hline \multirow[t]{2}{*}{ Volume of urine excreted $(\mathrm{mL})$} & $243.1 \pm 62.8$ & $289.7 \pm 86.2$ & $0.063^{\mathrm{b}}$ \\
\hline & $230(150-400)$ & $322(150-400)$ & \\
\hline Postvoid residual volume $(\mathrm{mL})$ & $112.5 \pm 17.8$ & $190 \pm 23.3$ & $0.00 \mathrm{I}^{\mathrm{a}}$ \\
\hline Patients who needed urinary catheterization & I (5.6\%) & $3(16.7 \%)$ & $0.603^{c}$ \\
\hline
\end{tabular}

Notes: Values are expressed as mean \pm SD and/or median (minimum-maximum). alndependent $t$-test. ' ${ }^{\circ}$ Mann-Whitney $U$ test. 'Fischer's exact test, treatment=IM injection of neostigmine or $\mathrm{NaCl} 0.9 \%$.

Abbreviations: $\mathrm{C}$, control group; IM, intramuscular; N, neostigmine group; $n$, number of subjects.

M3 subtype in the detrusor, but M3 subtype was confirmed to be the major contraction receptor. ${ }^{15,16}$

In our study, IM neostigmine effectively accelerates bladder emptying. Time to first voiding after IM injection and time to first voiding after spinal anesthesia were significantly faster in the $\mathrm{N}$ group. The postvoid residual volume was also significantly lower in the $\mathrm{N}$ group, which indicates that neostigmine improves muscle contraction after spinal anesthesia. However, the effectiveness of IM neostigmine to accelerate bladder emptying was not followed by significant reduction in incidence of POUR and urinary catheterization in the $\mathrm{N}$ group. One (5.6\%) subject in the $\mathrm{N}$ group and three (16.7\%) subjects in C group were catheterized due to urinary retention. This phenomenon could be caused by patient's age and type of surgery in our study. Lower abdominal (except for pelvic, urologic, anorectal, and hernia surgery) and lower extremity surgery were considered as of low-risk for POUR. Incidence of POUR has been shown to increase with age, and the risk increases at age $>50$ years. Hence, effectiveness of IM neostigmine to accelerate bladder emptying might be masked by low incidence rate of POUR in our study. Further research with large sample and high-risk surgery is needed to confirm this presumption.

\section{Conclusion}

This study indicated that IM neostigmine effectively accelerates bladder emptying after spinal anesthesia but did not decrease the incidence of POUR and frequency of urinary bladder catheterization in patients undergoing lower abdominal (except for pelvic, urologic, anorectal, and hernia surgery) and lower extremity surgery under spinal anesthesia.

\section{Acknowledgment}

This research received no specific grant from any funding agency in the public, commercial, or not-for-profit sectors.

\section{Disclosure}

The authors report no conflicts of interest in this work.

\section{References}

1. Baldini G, Bagry H, Aprikian A, Carli F. Postoperative urinary retention: anesthetic and perioperative considerations. Anesthesiology. 2009;110(5):1139-1157.

2. Pavlin DJ, Pavlin EG, Fitzgibbon DR, Koerschgen ME, Plitt TM. Management of bladder function after outpatient surgery. Anesthesiology. 1999;91(1):42-50.

3. Stallard S, Prescott S. Postoperative urinary retention in general surgical patients. Br J Surg. 1988;75(11):1141-1143.

4. Geller EJ. Prevention and management of postoperative urinary retention after urogynecologic surgery. Int J Womens Health. 2014;6: 829-838.

5. Kamphuis ET, Ionescu TI, Kuipers PW, de Gier J, van Venrooij GE, Boon TA. Recovery of storage and emptying functions of the urinary bladder after spinal anesthesia with lidocaine and with bupivacaine in men. Anesthesiology. 1998;88(2):310-316.

6. Choi S, Mahon P, Awad IT. Neuraxial anesthesia and bladder dysfunction in the perioperative period: a systematic review. Can J Anaesth. 2012;59(7):681-703.

7. Niazi AA, Taha MA. Postoperative urinary retention after general and spinal anesthesia in orthopedic surgical patients. Egypt J Anaesth. 2015;31(1):65-69.

8. Ozturk NK, Kavakli AS. Use of bladder volume measurement assessed with ultrasound to predict postoperative urinary retention. North Clin Istanb. 2016;3(3):209-216.

9. Dicuio M, Pomara G, Menchini Fabris F, Ales V, Dahlstrand C, Morelli G. Measurements of urinary bladder volume: comparison of five ultrasound calculation methods in volunteers. Arch Ital Urol Androl. 2005;77(1):60-62.

10. Buckley BS, Lapitan MC. Drugs for treatment of urinary retention after surgery in adults. Cochrane Database Syst Rev. 2010; 10(10):CD008023.

11. Taylor P. Anticholinesterase agents. In: Brunton LL, Chabner BA, Knollmann BC, editors. Goodman and Gilman's The Pharmacological Basis of Therapeutics. 12th ed. New York: McGraw-Hill; 2011: 1237-1275.

12. Nakahara T, Kubota Y, Sakamoto K, Ishii K. The role of cholinesterases in rat urinary bladder contractility. Urol Res. 2003;31(3): 223-226.

13. Hegde SS, Eglen RM. Muscarinic receptor subtypes modulating smooth muscle contractility in the urinary bladder. Life Sci. 1999;64(6-7): 419-428. 
14. Bałkota M, Tomaszewski D, Truszczyński A, Sokół-Kobielska E. Skuteczność domięśniowo podawanej neostygminy w zapobieganiu zatrzymania moczu u chorych znieczulanych podpajęczynówkowo [The efficacy of the intramuscularly administered neostigmine in the prevention of urinary retention after spinal anesthesia]. Lek Wojsk. 2013;91(4): $410-415$.
15. Mokry J, Svihra J, Nosalova G, Kliment J. Mechanisms of reactivity of urinary bladder smooth muscle. Bratisl Lek Listy. 2002;103(9): 279-282.

16. Giglio D, Tobin G. Muscarinic receptor subtypes in the lower urinary tract. Pharmacology. 2009;83(5):259-269.

\section{Publish your work in this journal}

Therapeutics and Clinical Risk Management is an international, peerreviewed journal of clinical therapeutics and risk management, focusing on concise rapid reporting of clinical studies in all therapeutic areas, outcomes, safety, and programs for the effective, safe, and sustained use of medicines. This journal is indexed on PubMed Central, CAS,
EMBase, Scopus and the Elsevier Bibliographic databases. The manuscript management system is completely online and includes a very quick and fair peer-review system, which is all easy to use. Visit http://www.dovepress.com/testimonials.php to read real quotes from published authors.

Submit your manuscript here: http://www.dovepress.com/therapeutics-and-clinical-risk-management-journal 